University of Michigan Law School

University of Michigan Law School Scholarship Repository

\title{
Is the Assignee of a Contract Liable for the Non-Performance of Delegated Duties?
}

Grover C. Grismore

University of Michigan Law School

Available at: https://repository.law.umich.edu/articles/1167

Follow this and additional works at: https://repository.law.umich.edu/articles

Part of the Contracts Commons

\section{Recommended Citation}

Grismore, Grover C. "Is the Assignee of a Contract Liable for the Non-Performance of Delegated Duties?" Mich. L. Rev. 18 (1920): 284-95.

This Article is brought to you for free and open access by the Faculty Scholarship at University of Michigan Law School Scholarship Repository. It has been accepted for inclusion in Articles by an authorized administrator of University of Michigan Law School Scholarship Repository. For more information, please contact mlaw.repository@umich.edu. 


\section{IS THE ASSIGNEE OF A CONTRAC'T ${ }^{1}$ LIABLE FOR THE NON-PERFORMANCE OF DELEGATED DUTIES?}

$\mathbf{I}^{\mathrm{T}}$

is an oft recurring statement that "rights arising out of a contract cannot be transferred if they are coupled with liabilities."2 It is such obscure statements as this which give rise to and perpetuate error, and an examination of the cases will show that this one has been responsible for no little confusion in regard to the matter of assignment in the law of Contract. Our courts, under the pressure of a well filled docket, are prone to seize upon a broad generalization of this kind without examining its true meaning or defining its proper limitations. It is high time for us to do away with such archaic conceptions and to recognize what the modern business man assumes, viz: that contract rights may be as freely transferred as any other species of property. That much has already been accomplished is evident from a perusal of the recent literature on the subject. ${ }^{3}$ But there is more work to be done, for there are still supposed rules of law which tend to defeat the reasonable expectations of the parties and consequently to hamper the transfer of rights. Such rules do not deserve to be perpetuated if there is any rational basis for a contrary holding.

The recent case of Mound Valley Vitrified Brick Co. v. Mound Valley Natural Gus and Oil Co. et al illustrates what seems to be an incorrect application of the so-called rule above quoted and raises à question of considerable practical importance. A entered into a contract with $B$ whereby he agreed to supply $B$ with suffi-

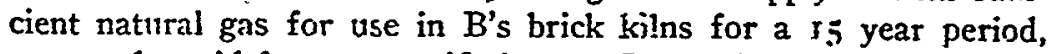
same to be paid for at a specified rate. Later the contract was assigned to $\mathrm{C}$ by $\mathrm{A}$ by a written agreement in which $\mathrm{A}$ did "sell, assign and transfer" all his "right and title" to the contract to C. C

2The phrase "assignee of a contract" is obviously inaccurate, because it gives rise. to the inference that a contract is a single relation, whereas it is in fact a complex conception involving numerous legal relations of different kinds, some of which are and others of which are not assignable. The phrase has been used here because of its convenience and because it is a part of the generally accepted terminology. It would be more correct to speak of the assignee of the rights, privileges, powers and immunities conferred by a contract.

2 Pollock on Contracts (3rd Am. Ed.) 594.

"See "The Alienability of Choses in Action" by W. W. Cook, 29 HARv. L. REv. 8:6 and 30 Id.. 449, also "Is the Right of An Asignee of A Chose in Action Legal or Equitable?" bv Samuel Williston, 30 Id. 97.

(1919). 258 Fed. 936. 
entered upon the performance of the agreement and fulfilled all its terms for a period of more than four years after which he refused to perform further. $B$ thereupon brought a suit at law against $A$ and $C$ jointly to recover in damages for breach of contract. It was held by the court that $A$ was liable but that $C$ was not. on the ground that "While contract rights may be assigned by one party to a contract without the consent of another, contract obligations may not be so assigned. In other words, where a personal contract involves not oniy mutual rights of the parties thereto but also mutual obligatintis, as in this case, both parties must consent to an assignment to make it effective."s

The case presents a situation which is likely to develop whenever it is attempted to make an assignment in general terms of a contract as such, and a careful analysis will show that there are involver at least five separate and distinct questions, viz: (I) May rights conferred by a contract, the enjoyment of which is dependent upon the performance of duties, be assigned? (2) May the assignor assign duties imposed upon him by the contract, without the consent of the other contracting party? (3) May the assignor delegate to the assignee the performance of duties under the contract? (4) Does an assignment in general terms, which purports to assign the contract as such, embrace within itself a delegation of duties? (5) Assuming that duties have been delegated, does the assignee become liable either to the assignor or to the other contracting party in case he fails to perform them?

It is submitted that each of these questions involves a separate and distinct problem and that these problems cannct all be solved by the application of the convenient but misleading formula adopted by the court. An attempt will be made to reach a correct result by the application of rational and well settled principles. As a matter of fact it is the answer to only the last of these questions that occasions any real diffirulty in view of modert developments in the law of assignment.

That contract rights may be assigned even though thei- erijoyment is dependent upon the performance of certain specified duties is too well settled to admit of argument in spite of the inference to the contrary inherent in the portion of the opinion quoted supra."

\footnotetext{
Ibid 943. 544; Rodijkeit v. Andrews, 74 Oh. St. 104; O'Keefe v. Allen, 20 R. I. 414; Kone v.
} 
In so far as the case holds that the assignor may not by an assignment free himself from liability under the contract, no fault can be found with it. That the burdens of a contract cannot be transferred without the consent of the obligee is fundamental. "You have the right to the benefit you anticipate from the character, credit and substance of the party with whom you contract."? This it is believed is all that is ordinarily intended or that can legitimately be intended by the statement quoted. ${ }^{8}$

That it does not mean that the assignor may not delegate the performance of duties is evident from the fact that it is now generally admitted that the assignor may, in the absence of a clear indication in the contract itself of a contrary intention, delegate to the assignee the performance of duties unless the duties in question are of such a nature as to make it clear that the parties must have contemplated performance by the assignor personally.?

Whether the performance of the duties was delegated to the assignee is a question of fact to be determined in each case from a consideration of the nature of those duties, and from the acts of the parties and the language used by them. There is nothing in the case of the Mound Valley Vitrified Brick Co. v. The Mound Valley Natural Gas \& Oil Co., supra, to indicate that the duties involved were of such a personal nature as to be non-delegable. Such an assumption is expressly negatived by the fact that the other contracting party was not only willing but anxious to have the assignee perform them. That they were delegated seems a fair inference from the fact that the assignee did perform them for a period of more than four years. Moreover it has been held that an assignment

Clough, 36 Mich. 436. Such an assignment is not ineffectual although it purports to provide for a substitution of the assignee in the matter of duty and liability as pell as of right. $A \mathrm{~m}$. Lith. Co. v. Ziegler (1014), 216 Mass. 287. To be sure the assiznec takes the rights subject to any defenses available against the assignor by reason of.the latter's failure to perform conditions precedent or concurrent. Am. Lith. Co. v. Ziegler, Locus cit.

IHumble v. Hunter, Is Q. B. $310,317$.

- See Atlantic \& N. C. R. R. Co. v. Atlantic \& N. C. Co., 147 N. C. 368, 380 ;

Tollutst v. Associated Portland Cement Mfrs. [1902], 2 K. B. 660, 668.69.

- See the authorities cited in the preceding note and British Wagon Co. v. Lea, L. R.5 Q. B. D. 149; LaRue v. Groezinger, 84 Cal. 281 ; Liberty Wall Paper Co. v. Stoner 170 N. Y. 582 .

The confusion existing in regard to this whole matter is undoubtedly due in a large measure to the fact that the courts have not been careful in their choice of terminology. They have used the phrase "assignment of contract" to refer indiscriminately to situa. tions that are fundamentally different. The phrase ought to be discarded entirely. See for an analysis of what the phrase connotes and for a discussion of the underlying principles "Assignability of Contract" by F. C. Woodward. 18 HArv. L. REv. 23. 
in general terms, such as this was, presumptively carries with it a delegation of the duties upon the performance of which the enjoyment of rights is dependent. ${ }^{10}$ This presumption seems reasonable in view of the quite evident understanding of the parties in the ordinary transaction of this kind.

The answer to the question as to whether or not the assignee is liable for the non-performance of delegated duties is not so clear and requires a careful analysis of the operative fact of assignment and its incidents. It may be admitted at the outset that an assignment does not, except in the case of covenants running with the land, ${ }^{102}$ create privity either of estate or contract between the assignee and the other contracting party in the sense in which this chameleon-like term is generally used in the law. ${ }^{11}$ But the conclusion that he is not liable does not, as is sometimes erroneously assumed, ${ }^{12}$ follow inevitably from this admission, for there are at least two classes of cases in which many courts recognize and enforce rights in favor of one who is not privy to the contract. This is true (I) in the case of the assignee of rights under a contract, ${ }^{122}$ and (2) in the case of a third party beneficiary.13 If therefore it should appear that the acceptance of an assignment in general terms, which embraces a delegation of duties as well as a transfer of rights, imports a promise on sufficient consideration made by the assignee to the assignor whereby the former assumes to perform delegated duties, and that this promise is one "for the benefit of" the other party to the contract assigned, then the latter's right to enforce the promise would seem to be clear, at least in those jurisdictions in which a creditor-beneficiary is given a right of action.

There can never be any question as to the sufficiency of the consideration in the normal case where the assignment is not gratuitous and rights are conferrred upon the assignee thereby. As to whether the asignee does make such an assumption is, of course, a

\footnotetext{
I4 Pioneer Loan and Land Co. v. Cowden, 128 Minn. 307.

See also Gribling r. Bohas, 26 Cal. App. 77 r.

20 This statement requires explanation. It is not the assignment of the contractual rights and duties that creates the privity of estate here but rather the assignment, or more properly, the conveyznce of the estate in the land, to which the contractual rights and duties are incident, that creates the privity.

21 For an interesting comment on the use of this term see I5 Ax. L. REv, 244-45.

= See, e. 8 ., the superficial reasoning indulged in to prove the point in $2 R$. L. 626 .

12e See Tolkurst v. Associated Portland Cement Mfrs. [3902], 2 K. B. 660 at 668.

2 See cases on this matter together with the underlying principles discussed in 27

YaIe Lay Jourkas zo08: is Harv. L. REv. 767.
} 
question to be determined by an interpretation of the contract incident to the assignment. We may put aside for the present those cases in which the parties expressly stipulate that the assignee shall assume the burdens. In such a case the assignee is obviously liable to the assignor for the non-fulfillment of his promise. As to whether he is also liable to the other party to the contract assigned depends upon whether his promise is one "for the benefit of" the latter, a question which we will consider presently. The cases which cause the most difficulty are the numerous ones in which the assignment is in the general terms- "the assignor does hereby sell, assign and transfer all his right and title to the within contract." It is submitted that the acceptance of an assignment in this form does presumptively import a tacit promise on the part of the assignee to assume the burdens of the contract, and that this presumption should prevail in the absence of the clear showing of a contrary intention. The presumption seems reasonable in view of the evident expectation of the parties. The assignment on its face indicates an intent to do more than simply to transfer the benefits assured by the contract. It purports to transfer the contract as a whole, and since the contract is made up of both benefits and burdens both must be intended to be included. It is true the assignor has power only to delegate and not to transfer the performance of duties as against the other party to the contract assigned, but this does not prevent the assignor and the assignee from shifting the burden of performance as between themselves. Moreover common sense tells us that the assignor, after making such an assignment, usually regards himself as no longer a party to the contract. He does not and, from the nature of things, cannot easily keep in touch with what is being done in order properly to protect his interests if he alone is to be liable for non-performance. Not infrequently the assignor makes an assignment because he is unable to perform further or because he intends to disable himself for further performance.14 The assignee on the other hand understands that he is to carry out the terms of the contract, as is shown by the fact that he usually does, most of the decided cases being those in which the other party objected to performance by the assignee. In view of these considerations is it not reasonable to infer that the assignee tacitly promises to perform? It is no answer to say that the assignor should take an express promise-a thing

\footnotetext{
i See Tolkurst v. Associeted Portlend Cement Mfrs. [1903], A. C. 414.
} 
which he probably would do were he familiar with the law on the subject. Moreover the implication of such a promise is not inconsistent with existing rules of law. In making it we are simply interpreting what the parties mean by their acts and the language used. That there is such a tacit promise has been affirmed in a few instances in which the assignor was permitted to recover for danages suffered by reason of the assignee's failure to perform delegated duties. ${ }^{15}$

'The liability in such a case has sometimes apparently been regarded as quasi-contractual. ${ }^{16}$ This is clearly erroneous. A promise inferred from the voluntary acts of a person may be as truly contractual as one expressed in so many words.

If this argument is sound, what is to prevent the other contracting party, as a creditor-beneficiary, from suing the assignee on his promise? It is true that the performance of the promise will benefit both the assignor and the other party to the contract assigned. But one need not be a sole beneficiary to have an enforcible right. Where the promisor has made a promise, the fulfilment of which necessarily requires him to do something directly for a third parsun, as is the case here, the latter is usually regarded as a beneficiary within the rule, even though the promisee is also and perhaps primarily intended to be benefited thereby. ${ }^{17}$ That the assignee is liable at the suit of the third party where he expressly assumes and promises to perform delegated duties has already been decided in a few cases. ${ }^{18}$ If an express promise will support an action, it - is difficult to see why a tacit promise should not have the same

16 Corvallis \& A. R. R. Co. v. Portland E. \& E. Ry Co. (1917), 84 Or. 524.

See also Cutting Packing Co. v. Packer's Exch., 86 Cal. 574. (The authority of this case is somewhat weakened by the fact that the decision is based partly on a statute.)

Atlontic \& N. C. R. R. Cn. v. Atlantic \& N. C. Co., I47 N. C. 368;

Union Pacific Ry. Co. v. Douglas County Bank, 42 Nebr. 469.

10 See Atlantic \& N. C. R. R. Cn. v. Atlentic \& N. C. Co., cited in preceding note. This has probably resulted from the confusion in the use of the term "implied contract" which is employed indiscriminately by the courts to refer to both kinds of obligations.

${ }^{17}$ Lazurerce v. For (1859), 20 N. Y. 268:

Ballard v. Home Nat'l Bark, gr Kans. 9x.

See also numerous cases collected is Harv. L. REv. $805 \mathrm{~N}$. II and IIt.

${ }^{8}$ Wiggins Ferry Co. v. The Chicago \& Alton, 73 Mo. 389; Back v. Boston ete. Mirsing Co., 16 Mont. 467 ; Ynurse v. Brnad Road ,L.br. Co., 148 N. C. 34.

Contra: Goodyear Shoe Machinery Co. v. Dencel, ing Fed. 692:

Turrer v. MCCarty, 22 Mich. 264. The Federal courts apparently deny the right of a creditor-beneficiary in any case. See National Bank v. Grand Lodge, 98 U. S. 223. The same has heretofore been true i.t Michigan. But see $28 \mathrm{MrcH}$. L. Rxv. 58. 
effect. ${ }^{19}$ The assignor and the assignee could not, of course, be joined in a suit at law under the generally prevailing procedure, as was attempted in Mound Valley Vitrified Brick Co. v. Mound Valley Natural Gas \& Oil Co., ${ }^{20}$ inasmuch as the liability of each arises on a separate and distinct contract.

The hardship that is likely to result from the contrary holding is well illustrated by the case of Tolhurst v. Associated Portland $\mathrm{Ce}$ ment Mfrs., ${ }^{21}$ in which A agreed to supply chalk to B Co. for use in its cement works for a period of 50 years at a specified price per ton. B Co. later assigned to C Co. and went out of business, distributing all its assets so that it remained in existence in name only. The court, at the suit of the assignee, held the assignment effectual; Collins, M. R. saying "There is certainly an apparent hardship, unless he accepts the new company instead of the old, that whereas before the assignment he had a solvent company to deal with against whom he had an effectual remedy if they refused to perform the contract, now, if the price of chalk were to fall below Is, $3 \mathrm{~d}$., and the new company no longer cared to take it at that price. his only remedy would be against a company wholly denuded of assets." 22 This is, to say the least, a startling proposition and involves a risk which the other party to the contract assigned ought not in justice to be compelled to assume. Ought a court not to say, what was said in the case of Wightman v. Spofford," that "When Spofford accepted the contract, as assignee, and became clothed with all the rights conferred by it, he assumed all the obligations of his assignor. He could not hold plaintiff to the terms of the contract and stand himself discharged from it. This conclusion is based upon the plainest principles of equity. Familiar principles of law impose on him, upon accepting the assignment and taking the place of Townsend. the obligation to perform Townsend's covenants and render him liable for failure to perform them."

It must, however, be admitted that the current of the authorities

10 The contrary holding in Lisenby v. Newlon, 120 Cal. 571, seems to be based upon the interpretation of a statute.

2 Locus cit. supra note 4.

2I [s,02], 2. K. B. 660 .

22 Ibid 674.

$\Rightarrow 56$ Iowa 145,148 . In this case the assignee of a bond conditiones upon the conveyance of certain land on payment of the agreed price was held liable in equity at the suit of the vendor for non-payment of the stipulated installments of the purchase price. 
is opposed to the view here advocated, ${ }^{24}$ but it is believed by the writer that this has resulted from a misapprehension of the problem involved, and from a failure to discriminate between cases that resemble each other but are essentially different.

The liability of the assignee has frequently been denied in cases involving an assignment by one of the parties to a contract for the purchase of land. In some of these cases the decision is rested upon the narrow ground of want of privity. ${ }^{25}$ This is perhaps not to be wondered at in view of the fact that our real property law has always been encumbered with nice distinctions in regard to privity. It is not strange, therefore, that the legal mind should find it difficult to break away from adherence to this fetish when a contract relating to land is at stake, and should try to solve every problem in connection with it by an application of the rules relating to covenants running with the land. But it is one thing to say that privity of estate is essential to create liability when one takes a conveyance of land which was subject to contractual burdens in the hands of the grantor, of which the grantee probably had no actual knowledge, and a quite different thing to apply the same ine of reasoning to a case where one takes an assignment of a contract knowing that it embraces both rights and duties. The two cases are very different, for the grantor of land does not, in the ordinary case at least, as does the assignor of a contract, purport to transfer any contractual rights or duties, but simply to alien a certain estate in the land which estate is made up of rights and duties in rem. There is therefore no reason fur saying that the grantee by accepting the conveyance promises to assume the contractual relations entered into by prior holders of that estate.

In other cases the assignee's immunity has been placed upon the ground that his position is analogous to that of the grantee of land who takes it subject to a mortgage but does not expressly assume to pay the mortgage. ${ }^{29}$ However, as is said in Wightman v. Spof-

9 The statement in 18 HAxv. L. RFv. 28 that "the assignment is a distinct beneft to the seller, for by its operation he acquires a right of action against the assignee," unfortunately does not seem to be supported by the authorities. The cases there cited are those in which the assignee expressly promised to perform delegated duties.

* Southern Pac. Co. v. Butterfield (1916), 39 Nev. I77; Cote v. Olson (Sask 1912), 2 D. L. R. 392 (semble).

See also Midland County Savings Bank v. T. C. Prouty Co., 158 Mfich. 656.

\$ Fisher v. Brown, 24 W. Va. 713; Lavelle v. Gordon, Is Mont. 5Is: Hammer v. Joknsor, 44 IIl. I92. 
ford, $=\pi$ the analogy is nut at all perfect. The same dissimilarity exists here that was pointed out above, viz. the grantor of land subject to a mortgage does not purport to assign the mortgage but simply to transfer his estaie in the land. Moreover it seenis that even the grantee in such a case may be liable for non-payment of the mortgage debt witi:out an express assumption if the circumstances are such as to show a tacit promise to pay-e. g., where he keeps back frart of the consideration for that purpose.."s

To be sure the assignee ought not to be held liable tor the nonperformance of duties where it clearly appears that he did not assume the burdens of the contract. It is obvious that there may be merely an assignment of rights, the intention being that the assignor shall alone continie liable to perform the duties. Of this kind is the case of Tolerton $\&$ Stetson Co. v. Anglo-Californic Bank, in which the seiler of a car of canned goods, who had warranted them, consigneri the goods to the defendant bank and scit the bill of lading with draft attached to the defendant. Plaintiff paid the draft and accepted the goods but later, upon learning that the warranty had not been fulfilled, brought suit against the bank for breach of it, on the theory that the bank was an assignee of the contract of sale and therefore became liable on the warranty. The court held quite properly that no such liability had been incurred by the bank. ${ }^{30}$ There had been no assignment in general terms of the contract as such, and as the court points out, there was clearly no intention to assume the duty to fulfill the warranty. "What was in fact done by the assignment of the draft and bill of lading, was to transfer to the bank the canneries company's right- to the price, and to give it the possession of the goods as security." In so far as the cases of Finch v. Gregg ${ }^{31}$ and Landa v. Lattin Bros., ${ }^{32}$ which appear to be on all fours with the foregoing case, announce a contrary rule, they must be disapproved as the holdings are not consistent wiih the facts involved.

\footnotetext{
2756 Iowa 145.

3 Twichell v. Mears, 8 Biss. 21I: Comstock v. Hits, 37 IIl. 542 (sembie).

29 I 2 Iowa 706. See also Gammel Book Co. v. Paine, 75 Nebr. 683.

$\infty$ It is to be noted that the suit in this case was brought for breach of warranty. It is of course obvious that the bank was not entitled to collect more, in the first instance, than the seller himself could bave collected. Whether it was liable to the buyer on the quasi-contractual ground that it had received money which-it could not equitably retain is a question outside tive scope of this article.

\$1 $126 \mathrm{~N}$. C. 176.

Iq Tex. Civ. App. 246.
} 
The assignee's liability has also frequertly been in issue in cascs involving the assignment of leases. The problem is rendered more difficult of solution bere by reason of the fact that the word, "lease," is a word of no precise connotation. In its primary signification it denotes the conveyance of an estate in land, 's and in this sense it has very little in common with the term cuntrati. It is "also used in a more extended sense to describe not only the legal act (the conveyance) by which a lesser estate is restcd $i: 2$ another, but, in addition, the legal act or acts by which variusus contractual obligations are created in connection with such cunveyance." in this sense we may speak of it as a contract." The phrase, "assignment of a lease," may therefcre refer to either one of two things. (I) It may mean simply the transfer of the estate, or rights and duties in rem of the-lessee; or (2) it may refer to what purports to be a transfer of the estate of the lessee plus the contractual rights and duties entered into and existing as incident to the estate. Where the lessee makes an assignment in the sense first indicated, it is clear that there is no ground for saying that the asignee by accepting the assignment assumes the contractual burdens incident to the estate, except in so far as the law imposes liability upon him because of the privity of estate, for the reason that an assignment in this form does not purport to transfer any rights or duties in personam. It purports to transfer simply rights and duties in rem, and, perhaps, to create new rights and duties in porsonam between the assignor and the assignee. This seems to be the situation where the so-called assignment is in form a sub-lease. ${ }^{38}$ But where the lessee does more than simply to transfer his estate, by purporting to transfer a "lease," using that term in its more extended sense as including the contractual rights and duties inci-

2 alackstone's Cors. 317.

4 I Tiffaky, Landlord and Tenait 159-60.

4 Cf. Austix's Jurisprudence (5th ed.) 376 where it is said: "Rights in rem sometimes arise from an instrument which is called a contract, and are therefore said to arise from a cortract: the instrument in these cases wears a double aspect, or has a two-fold effect: to one purpose it gives itus in peraonam and is a contract, to another purpose it gives jus in rem and is a conveyance. When a so-called contract passes an estate, or, in the language of the nodern Civilinns, a right in rem, to the obligor, it is to that extent not a contract but a convcyance; a!though it may be a contract to some other extent and considered from some othes asyect."

n The transfer of a terant's entire interest even though in form a sub-lease is Benerally regarded as an assignment.

Craig v. Summers, 47 Minn. $189 ;$ St. Joseph \& St. L. R. R. Co. v. St. L., I. M. E S. R,. Cn., 135 Mo. 173; Mulligan v. Hollingsworth, 99 Fed. 216. 
dent to the estate, ${ }^{8 \tau}$ then we Have the same question that arises in any case where the assignor attempts to transfer a contract as such. In such a case it seems not unreasonable to say that the assignee, in accepting the assignment, does tacitly promise to perform the obligations of the contract.

Since the assignee of a lease is in all cases liable because of privity of estate on all covenants and promises which run with the land, the question becomes acute only, $(I)$ in the case of so-called personal covenants which do not "touch and concern the thing demised" and consequently do not run with the land, and (2) in case there have been successive assignments, and an attempt is made to hold an assignee liable for breaches occurring after he has reassigned and thereby destroyed the privity of estate necessary to create liability based on the doctrine of covenants running with the land. No extended examination of the cases will be attempted, since the courts, without stopping to consider the nature or purport of the assignment, have held, quite uniformly, that the assignee is not liable in either one of these cases in the absence of an express assumption of liability. ${ }^{88}$ This is not strange in view of the fact that the law relating to leases was definitely settled long before the advent of the doctrine giving a third party ber.eficiary a right of action. It would perhajs not he wise for the courts themselves to change such a well settled rule of law, but it is a strange rule that enables one to escape a just liability by shifting the burden to an insolvent. 30

A. due recognition of the fact that the assignee does, in such a case, tacitly promise to perform the covenants of the lease would make unnecessary such an anomalous decision as that in Mann v. Ferdinand Munch Brewery ${ }^{40}$ where the court had to do violence to the fundamental principles of contract law to find a basis for holding the dispossessed assignee liable on the covenants of the lease.

II is submitted that this is what is ordinarily intended where the assignment is in this form: "the lessee does hereby sell. assign and transfer the within lease."

a Ttrfaky, Landiord akd Texant $987 \mathrm{n}$.

- Sée Johnson v. Sherman, I5 Cal. 287; Goss v. Wcodland Fire Brick Co., 4 Pa. Sup. C. 167

225 N. Y. 189: noted in 17 Mrcm. L. REv. 512. In this case the assignee was held liable on the ground that he had made an express contract with the landlord to assume the covenants of the lease in consideration of the latter's consenting to the assignment, although the only evidence of such 2 contract was a letter $p r i t t e n$ by the assignee to the landlord nine months after the assignment and assent thereto, in which he said, "we will - " assume the lease." There pas no evidence of any intent to contract with the landlord, and, even if that difficulty were eliminated, there still remains the objection that the alleged consideration for the promise was a past consideration. 
No objection can be urged to a rule holding the assignee liable to the other party to the contract assigned, for non-performance of duties, where it is celar that there has been a tacit assumption of liability, that could not be made with equal force in any case in which a creditory-beneficiary claims a right of action. It is believed that the doctrine giving him a direct right of action, where there has been an express assumption of liability, has become well enough established and has demonstrated its usefulness to such a degree as to warrant its extension to cover this situation.

University of Michigan Law School.

Grover C. Grismore. 